Int. J. Dev. Biol. 55: 305-311 (2011)

doi: $10.1387 /$ ijdb.103145tn

\title{
Highly efficient cryopreservation of human induced pluripo- tent stem cells using a dimethyl sulfoxide-free solution
}

\author{
TATSUYA NISHIGAKI ${ }^{1}$,YUJITERAMURA ${ }^{2}$, AKIRA NASU $^{3}$, KEITAKADA $^{4}$, \\ JUNYATOGUCHIDA ${ }^{3}$ and HIROO IWATA*,1

\begin{abstract}
${ }^{1}$ Department of Reparative Materials, Institute for Frontier Medical Sciences, ${ }^{2}$ Radioisotope Research Center, Cell Research Center, Institute for Frontier Medical Sciences, Kyoto University, Kyoto, Japan
\end{abstract} \\ ${ }^{3}$ Department of Tissue Regeneration, Institute for Frontier Medical Sciences, ${ }^{4}$ Laboratory of Cell Processing, Stem
}

\begin{abstract}
Human induced pluripotent stem (hiPS) cells have great potential for regenerative medicine and drug discovery. It is essential to establish highly efficient and reliable methods for hiPS cell cryopreservation. We examined cryopreservation of hiPS cells by the vitrification method using a dimethyl sulfoxide $\mathrm{Me}_{2} \mathrm{SO}$-free and serum-free medium, VS2E, that uses Euro-Collins solution as a base with $40 \%(\mathrm{v} / \mathrm{v})$ ethylene glycol and $10 \%(\mathrm{w} / \mathrm{v})$ polyethylene glycol as cryoprotectants. This combination of vitrification and cryoprotectants resulted in a higher recovery rate of hiPS cells than with a commercially-available vitrification solution, DAP213, which contained $\mathrm{Me}_{2} \mathrm{SO}$ and serum components. After vitrification and warming, hiPS cells were cultured easily. Even after several subculturing steps, cells expressed undifferentiated cell markers, such as Oct-3/4 and SSEA-4, and also exhibited alkaline phosphatase activity. The pluripotency of hiPS cells was maintained, as demonstrated by teratoma formation upon hiPS cell transplantation into severe combined immunodeficient mice. Thus, we successfully preserved hiPS cells under liquid nitrogen with high efficiency using $\mathrm{Me}_{2} \mathrm{SO}$-free vitrification solution and rapid cooling.
\end{abstract}

KEY WORDS: cryopreservation, human induced pluripotent stem (iPS) cell, vitrification, $\mathrm{Me}_{2} \mathrm{SO}$-free, ethylene glycol

\section{Introduction}

Human embryonic stem (hES) and induced pluripotent stem (hiPS) cells are important in regenerative medicine and in drug discovery due to their pluripotent potential (Keller and Snodgrass, 1999; Ameen et al., 2008; Nakagawa et al., 2008; Takahashi et al., 2007; Yu et al., 2007). It is essential to establish methods for stably storing these stem cells, especially hiPS cells derived from patients with obstinate diseases. Cryopreservation using conventional slowfreezing methods results in low hiPS cell survival after thawing; further, a long culture period (at least 2 weeks) is required after thawing before experiments can be conducted (Reubinoff et al., 2001; Fujioka et al., 2004). Efficient cryopreservation and subsequent culture thus remain an obstacle to the effective use of hiPS.

Cryopreservation protocols developed for hES cells (Reubinoff et al., 2001; Fujioka et al., 2004; Richards et al., 2004; Ji et al., 2004) have also been used for hiPS cell cryopreservation. Although cell survival is improved compared to conventional methods, there is still room for improvement. Most cryopreservation media contain fetal bovine serum or serum-replacement and dimethyl sulfoxide ( $\left.\mathrm{Me}_{2} \mathrm{SO}\right)$. Ideally, components from animal serum or serumreplacement should not be included in the culture media to reduce the risks of infection by unknown pathogens in future regenerative medicine applications. $\mathrm{Me}_{2} \mathrm{SO}[\sim 1 \%(\mathrm{v} / \mathrm{v})]$ has been used for $\mathrm{ES}$ cell differentiation into mesendoderm (Ameen et al., 2008), and cryopreservation with slow freezing method using $\mathrm{Me}_{2} \mathrm{SO}$ reportedly induces ES cell differentiation (Katkov et al., 2006). Therefore, it is desirable to develop a cryopreservation medium that lacks both $\mathrm{Me}_{2} \mathrm{SO}$ and animal-derived components. Recently, the cryopreservation recovery ratios of $h E S$ and hiPS cells was improved by using Rho-associated coiled-coil kinase (ROCK) inhibitor (Martin-lbañez et al., 2008; Li et al., 2009; Claassen et al., 2009; Mollamohammadi et al., 2009); however, cryopreservation with the ROCK inhibitor is

Abbreviations used in this paper: DSC, differential scanning calorimeter; hES, human embryonic stem cell; hiPS, human induced pluripotent stem cell; SPR, surface plasmon resonance; SUV, small unilamellar vesicle; $\mathrm{tBLM}$, tethered bilayer membrane.

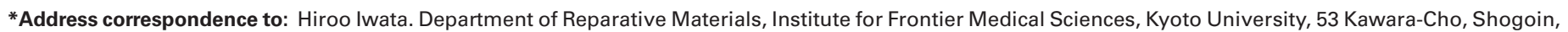
Sakyo-ku, Kyoto, 606-8507, Japan. Fax: +81-75-751-4119. e-mail: iwata@frontier.kyoto-u.ac.jp
}

Supplementary Material (two figures) for this paper is available at: http://dx.doi.org/10.17 


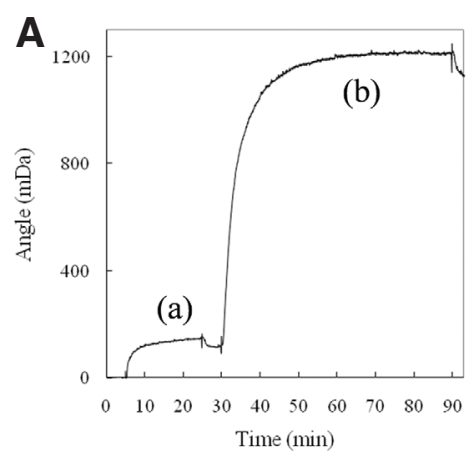

C

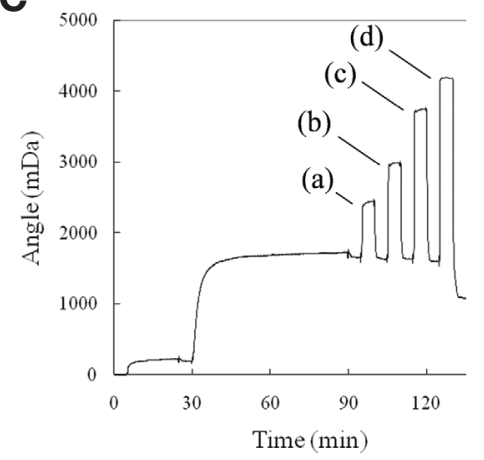

\section{B}

polyA-PEG-DPPE

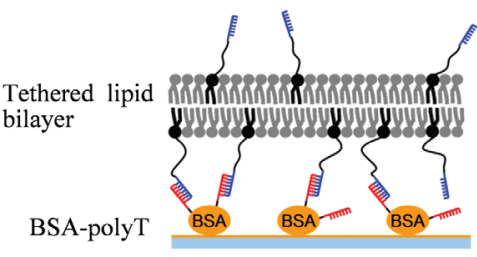

D

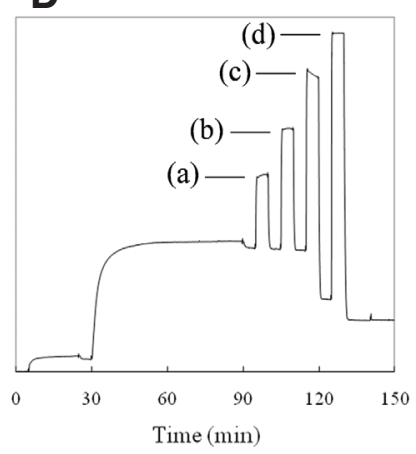

very time consuming, and the inhibitor might affect cell function. Thus, a simpler and more reliable method is needed.

Our group recently developed vitrification solutions for the cryopreservation of pancreatic islets and primate ES cells (Agudelo and Iwata, 2008; Agudelo et al., 2009; Nishigaki et al., 2010). These solutions do not contain $\mathrm{Me}_{2} \mathrm{SO}$ and animal-derived components; rather, the main components are ethylene glycol $(E G)$ and Euro-Collins solution. Our results suggested that diol compounds could replace $\mathrm{Me}_{2} \mathrm{SO}$ for cryopreservation. In the present study, we systematically examined the use of diol compounds, including $E G$, propane diol (PrD), butane diol (BuD), pentane diol (PeD), and polyethylene glycol (MW 200; PEG200) to improve the survival rate of hiPS cells after cryopreservation by vitrification. An alkaline phosphatase activity assay and immunostaining for Oct4 and SSEA- 4 were performed to evaluate the differentiation status of the hiPS cells. The potency of hiPS cells to differentiate into
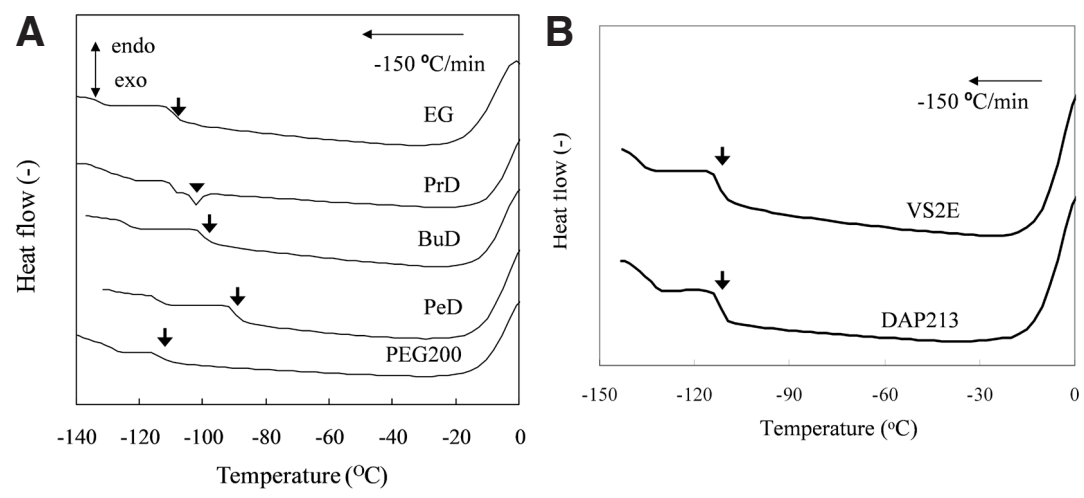

Fig. 2. Thermal analysis of (A) $40 \%$ diol compound solutions in Euro-Collins solution and (B) VS2E and DAP213 solution using differential scanning calorimetry (DSC). The chamber was cooled from 0 to $-140^{\circ} \mathrm{C}$ at a rate of $-150^{\circ} \mathrm{C} / \mathrm{min}$. Arrows indicate changes in the slope, and an arrowhead indicates an exothermic peak.

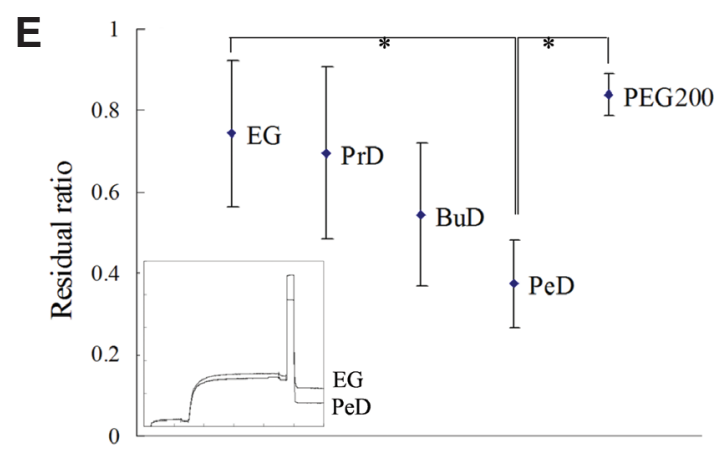

Fig. 1. Interaction between bilayer membrane and diol compounds. (A) Surface plasmon resonance (SPR) profile of the formation of the $L-\alpha$ phosphatidylcholine-tethered bilayer membrane (EggPC tBLM). A solution of polyT-BSA was applied to the Au surface (a), followed by application of polyA-EggPC (b). (B) Schematic showing EggPC tBLM formation on the $S P R$ sensor surface. (C,D) The interaction between EggPC $t B L M$ and (C) $E G$ or (D) PeD. After the formation of $t B L M$, (a) 5, (b) 10, (c) 20, and (d) $40 \%(V / V) E G$ (C) or PeD (D) solutions were applied sequentially (each for $5 \mathrm{~min}$ ). (E) Residual ratio of tBLM after exposure to the $40 \%$ diol solution. The residual ratios were calculated using the ratio of $t B L M$ before and after exposure to the diol compounds. The inset shows the SPR profiles of the interaction between $t B L M$ and $40 \% E G$ and PeD. All data are expressed as means $\pm S D$ for $n=3$. * Statistically significant difference $(p<0.05)$

three germ lines was also examined by transplantation of hiPS cells into severe combined immunodeficient (SCID) mice after the vitrification and warming procedure.

\section{Results and Discussion}

\section{Effects of diol solutions on tBLM}

In this study, we examined the use of four diol compounds, $\mathrm{HO}$ $\left(\mathrm{CH}_{2}\right)_{n}-\mathrm{OH}(\mathrm{n}=2-5)$, and poly(ethylene glycol) $\mathrm{HO}-\left(\mathrm{CH}_{2} \mathrm{CH}_{2} \mathrm{O}\right)_{n}-\mathrm{H}$ as cryoprotectants in a vitrification solution for hiPS cells. Surface plasmon resonance (SPR) was employed to investigate the interaction between a cell membrane and the diol compounds in vitro. A tethered bilayer membrane (tBLM) was formed on the SPR sensor surface and exposed to solutions with different concentrations of diols. tBLMs were prepared using the vesicle fusion method on a hydrophilic surface (Taylor et al., 2007; Chung et al., 2009). First, polyT-BSA was adsorbed on the SPR sensor surface, and then a suspension of polyA-PEG-DPPE-modified SUVs was applied to the surface. PolyT-BSA was effectively adsorbed on the Au surface (Fig. $1 \mathrm{Aa}$ ). The largest shift increase ( 1DA) was observed in the SPR profile when polyA-EggPC was applied to the polyTBSA-modified sensor surface (Fig. 1 Ab), indicating the formation of tBLM as shown schematically in Fig. 1B.

A cell membrane consists of a thin lipid bilayer that contains membrane proteins. The effects of diol compounds on cell membranes were examined by SPR using tBLM as a cell membrane model. The EggPC tBLM was exposed to increasingly concentrated diol solutions containing $5,10,20$, and $40 \%(\mathrm{v} / \mathrm{v})$ of diol in PBS for 5 min each, and then the surfaces were washed with PBS for $5 \mathrm{~min}$. The SPR signal intensities were monitored to determine whether diol compounds damaged the tBLM. Fig. 1 C,D show the SPR profiles 
A

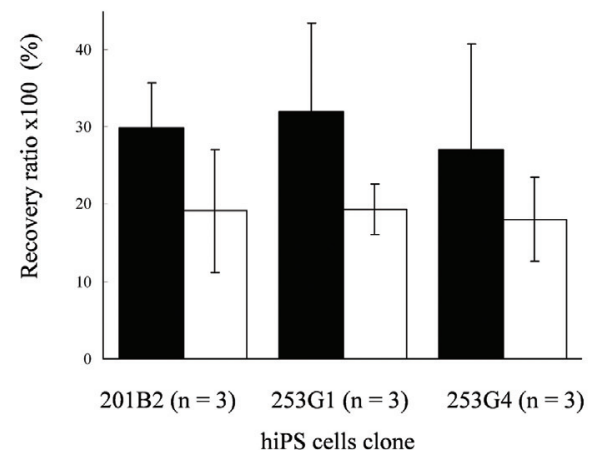

Fig. 3. Recovery rates of hiPS cells and colonies formed by hiPS cells after freezing and thawing. (A) Recovery rates of hiPS cells (clones: 201B2, 253G1, 253G4) 1 day after the cryopreservation and thawing procedure. hiPS cell were cryopreserved in VS2E (black bars) or DAP213 (white bars). The recovery rates were calculated by comparing the number of colonies 1 day after thawing/culture to the number of colonies formed by cells that were not cryopreserved. Results are expressed as means $\pm S D$ for $n=3$. (B) A phase contrast microscope image of cultured $253 G 1$ hiPS cells that were cryopreserved in VS2E 3 days after thawing. Scale bar: $500 \mu \mathrm{m}$.

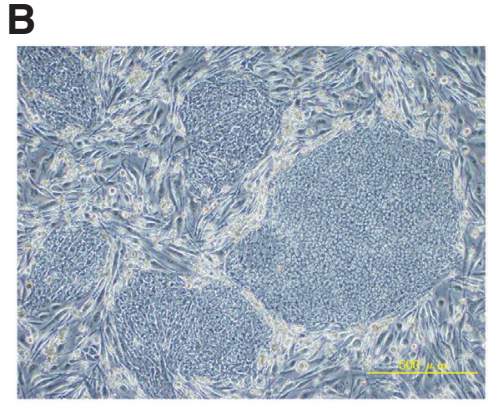

\section{of hiPS cells}

A vitrification solution of human ES cells (VS2E) was prepared using EG, PEG200, and Euro-Collins solution (Nishigaki et al., 2010). We examined various diols and their different concentrations to find a more suitable diol than EG for vitrification of hiPS cells (see Supplemental information). Although we had expected to find a more suitable diol than EG for vitrification, the results shown in Supplemental Fig. 1 and 2 indicated that EG was the most suitable diol for use in a vitrification solution.

when tBLMs were exposed to diol solutions of $5,10,20$, and $40 \%$ (v/v) EG or PeD, respectively. There was no change in the SPR signal intensity when the tBLM was washed with PBS after a 5, 10 , or $20 \%$ EG solution was applied, but the SPR signal intensity decreased after the $40 \%$ EG was applied. These results suggested that the tBLM remained intact when exposed to up to $20 \%$ EG but was damaged upon exposure to $40 \% \mathrm{EG}$. For PeD, the decrease in the SPR signal intensity began upon exposure to $20 \% \mathrm{PeD}$; thus, PeD interacted with or damaged the lipid bilayer membrane at lower concentrations than did EG. These experimental results indicated that the greater the hydrophobicity of the diol solution, the greater the damage to the cell membrane.

Fig. 1E shows the relative amounts of the residual lipid bilayer membrane when tBLM was exposed to $40 \%$ diol solutions. The amount of residual membrane decreased with increased diol molecular weight. The exception was PEG200: although it was the highest molecular weight compound used in this study, it did not damage the tBLM very much. PEG is a hydrophilic molecule, so presumably there was little or no interaction with the lipid b:layer membrane. In general, hydrophobic diol compounds with longer alkyl chain damaged the bilayer membrane.

\section{Thermal properties of cryopreservation solutions during the cooling process}

Effective vitrification is important for cryopreservation of hiPS cells. DSC analyses were carried out to monitor ice crystal formation in solutions of diol compounds in Euro-Collins solution. Fig. $2 \mathrm{~A}$ shows DSC charts of $40 \%(\mathrm{v} / \mathrm{v})$ diol solutions during cooling at a rate of $-150^{\circ} \mathrm{C} / \mathrm{min}$. The slopes of the DSC curves of EG, BuD, $\mathrm{PeD}$, and PEG200 solutions changed at around $-110,-106,-90$, and $-115^{\circ} \mathrm{C}$ (indicated by arrows). Those points indicate when the glass-transition phase change occurred. When the solutions in cryotubes were immersed directly into liquid nitrogen, the solutions remained transparent. These data indicate that the diol solutions were vitrified effectively. However, an exothermic peak was observed for the $\operatorname{PrD}$ solution at around $-105^{\circ} \mathrm{C}$, as indicated by an arrowhead in Fig. 2A. This could be attributed to crystallization of the PrD solution, and indeed it has been reported that PrD tends
In this study, we examined VS2E solution to cryopreserve hiPS cells, because various characters of hiPS cells are similar to those of hES cells.

Acommercially available solution that contains $\mathrm{Me}_{2} \mathrm{SO}$ and serum components, DAP213, is currently used for cryopreservation of ES cells and iPS cells. We compared vitrification using our solution, VS2E, with vitrification using DAP213. The compositions of these solutions are shown in Table 1. These cryopreservation solutions were analyzed using DSC (Fig. 2B) at a cooling rate of $-150^{\circ} \mathrm{C} /$ $\min$. No exothermic peak was observed for crystallization in either the DAP213 or VS2E solution. The slope changes around $-110^{\circ} \mathrm{C}$, indicating the glass-transition phase change (arrows in Fig. 2B), were observed for both solutions. Both solutions remained transparent after immersion into liquid nitrogen. These results indicate the two solutions were vitrified by rapid cooling.

hiPS cells (253G1, 253G4, and 201B2) were preserved in liquid nitrogen using a combination of rapid cooling and vitrification solution VS2E or DAP213. The recovery rates of these hiPS after vitrification and warming are summarized in Fig. $3 \mathrm{~A}$, and a phase contrast microscope image of hiPS cells cultured for 3 days is shown in Fig. 3B. The recovery rates of hiPS cell clones 201B2, 253G1, and 253G4, preserved by vitrification using VS2E were $29.8 \pm 5.8 \%(n=3), 32.0 \pm 11.4 \%(n=3)$, and $27.1 \pm 13.6 \%$ $(n=3)$, respectively. There was no significant difference in the

\section{TABLE 1}

\section{COMPOSITION OF THE CRYOPRESERVATION SOLUTIONS}

\begin{tabular}{lcc} 
& VS2E & DAP213 \\
\hline $\mathrm{Me}_{2} \mathrm{SO} \%(\mathrm{v} / \mathrm{v})$ & - & 14.2 \\
$\mathrm{EG} \%(\mathrm{v} / \mathrm{v})$ & 40 & - \\
$\mathrm{PG} \%(\mathrm{v} / \mathrm{v})$ & - & 22 \\
$\mathrm{PEG} \%(\mathrm{w} / \mathrm{v})$ & 10 & - \\
Acetamide \% (w/v) & - & 5.9 \\
DMEM/F12 with KSR & - & + \\
Euro-Collins & + & -
\end{tabular}

$\mathrm{Me}_{2} \mathrm{SO}$ : dimethyl sulfoxide; EG: ethylene glycol; PG: propylene glycol; PEG: polyethylene glycol (MW1000);DMEM/F12:Dulbecco's modified Eagle medium/F12; KSR:knockout serum replacement; Euro-Collins:34.95g/Ldextrose, $7.3 \mathrm{~g} / \mathrm{LK}_{2} \mathrm{HPO}_{4}, 2.04 \mathrm{~g} / \mathrm{LKH}_{2} \mathrm{PO}_{4}, 1.12 \mathrm{~g} / \mathrm{LKCl}$, and $0.84 \mathrm{~g} / \mathrm{LNaHCO}_{3}$. 

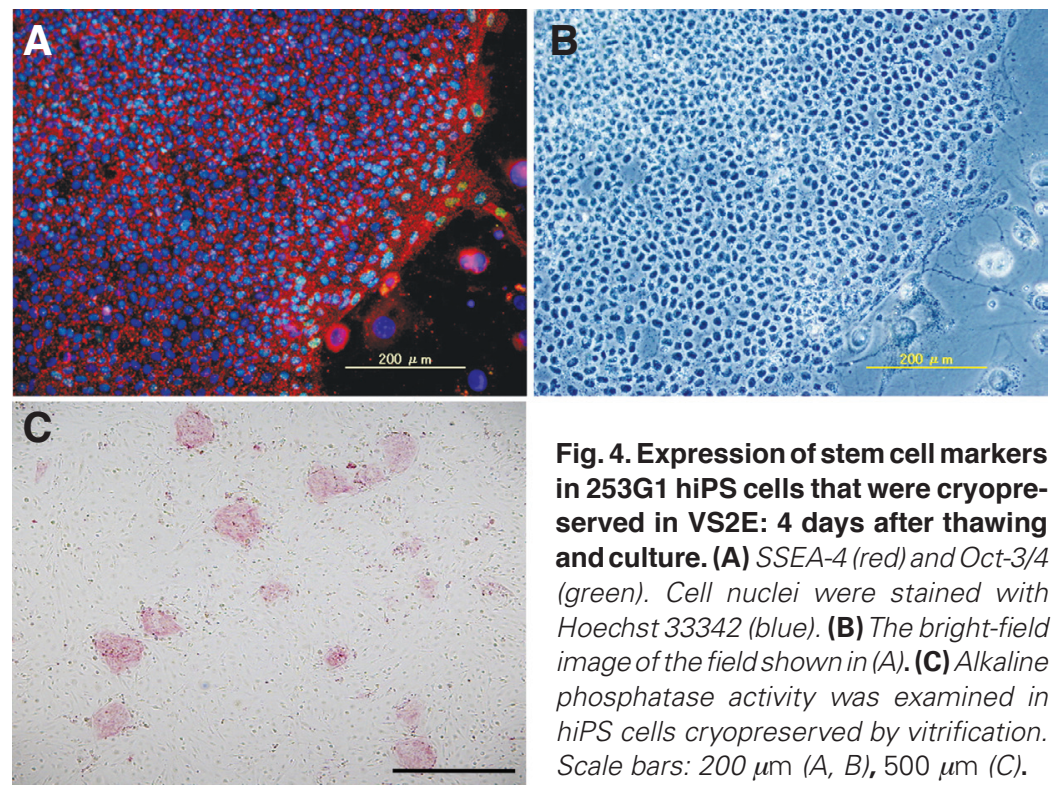

Fig. 4. Expression of stem cell markers in 253G1 hiPS cells that were cryopreserved in VS2E: 4 days after thawing and culture. (A) SSEA-4 (red) and Oct-3/4 (green). Cell nuclei were stained with Hoechst 33342 (b/ue). (B) The bright-field image of the field shown in (A). (C) Alkaline phosphatase activity was examined in hiPS cells cryopreserved by vitrification. Scale bars: $200 \mu \mathrm{m}$ (A, B), $500 \mu \mathrm{m}$ (C). colonies were formed after cryopreservation and thawing (data not shown) and it took 3 to 4 weeks to subculture hiPS cells. These results indicated that the slow freezing method is not suitable for cryopreservation of hiPS cells.

After hiPS cells were cryopreserved with VS2E and subsequently cultured for 4 days, colonies were analyzed immunohistochemically for undifferentiated cell markers SSEA-4 and Oct3/4 (Thomson et al., 1998; Sperger et al., 2003). The alkaline phosphatase activity of the hiPS cells was visualized after fixation with PFA. The hiPS cells exhibited alkaline phosphatase activity and expressed SSEA-4 and Oct3/4 (Fig. 4). The undifferentiated state was thus maintained in the hiPS cells after cryopreservation in VS2E under liquid nitrogen, thawing, and culture.

The pluripotency of the hiPS cells was examined by transplantation into SCID mice. Twelve weeks after transplantation, the teratomas formed from the injected cells were removed for histological examination. Fig. 5 shows HE-stained tissue sections from the teratomas. Endodermal epithelium, mesoderm-derived cells (muscle, cartilage), and neuroepithelium were identified in teratomas formed from 253G1 hiPS cells. Thus, histological recovery rates of the different clones. In addition, all of the hiPS cells proliferated well and those could be subcultured 3 days after seeded. These results indicated that the VS2E solution developed for vitrification of hES cells was suitable for cryopreservation of hiPS cells as well. In contrast, the recovery rates of hiPS cell clones 201B2, 253G1, and 253G4, preserved by vitrification using the commercially available solution, DAP213, were $19.3 \pm 3.3 \%$ $(n=3), 18.0 \pm 5.4 \%(n=3)$, and $19.1 \pm 8.0 \%(n=3)$, respectively.

Although the differences in recovery rates using VS2E and DAP213 were not significant, the recovery rates for the VS2E solution tended to be higher than those for DAP213. Although DAP213 is an effective vitrification solution (Fig. $3 A$ ), VS2E is preferable because it is free of $\mathrm{Me}_{2} \mathrm{SO}$ and serum components. In a series of experiments, we also cryopreserved hiPS cells (clone 253G1) using a conventional slow freezing method with $10 \% \mathrm{Me}_{2} \mathrm{SO}$. Only a few
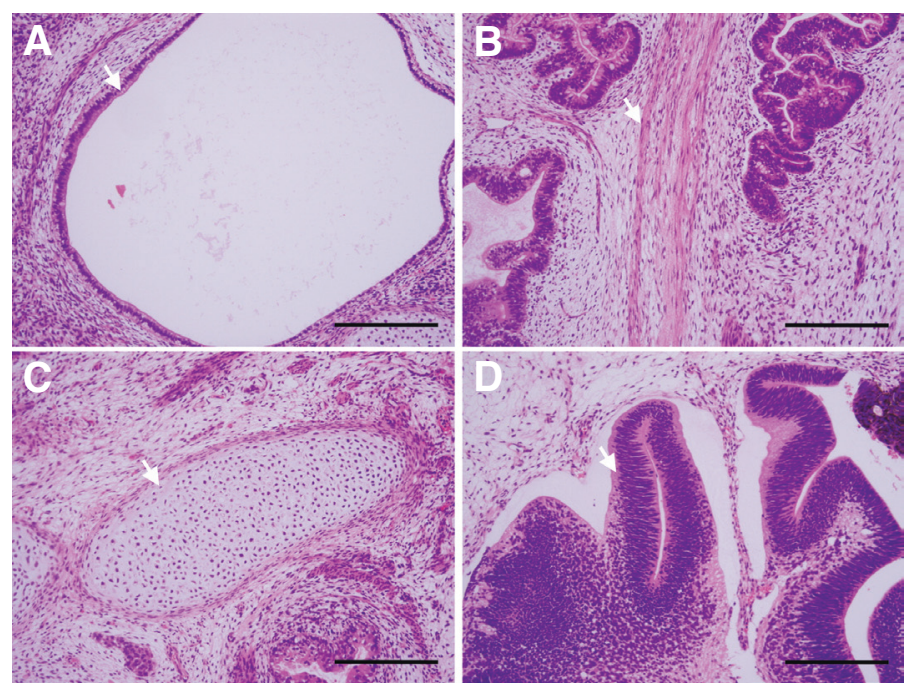

Fig. 5. Teratoma formation in SCID mice after transplantation of 253G1 hiPS cells cryopreserved in VS2E solution. Arrows indicate (A) endodermal epithelium, (B) muscle, (C) cartilage, and (D) neuroepithelium. Scale bars: $200 \mu \mathrm{m}$. analyses of the teratomas revealed that cryopreserved hiPS cells vitrified using VS2E and preserved under liquid nitrogen retained their pluripotency.

We meet some difficulties in cryopreservation of cells by vitrification. Those are troublesome procedures, a tube container with small diameter, the use of $\mathrm{Me}_{2} \mathrm{SO}$, and contamination risk from the direct contact with liquid nitrogen. In this study, we made some improvement in cell vitrification, such as use of a conventional cryotube, the simple solution without $\mathrm{Me}_{2} \mathrm{SO}$, and simple procedure.

\section{Conclusion}

We successfully cryopreserved and recovered hiPS cells using a vitrification solution composed of $40 \%$ (v/v) EG and $10 \%$ (v/v) PEG in Euro-Collins solution. EG was the most suitable diol compound for use in the vitrification solution. hiPS cells could be preserved under liquid nitrogen using VS2E solution combined with rapid cooling. The recovery rates were around $30 \%$, and the hiPS cells maintained pluripotency after cryopreservation using liquid nitrogen and subsequent thawing and culture. The cryopreservation solution VS2E thus has great potential for use in experimental research as well as in medical applications of hiPS cells.

\section{Experimental Protocols}

\section{Surface plasmon resonance (SPR)}

In this paper, we examined the interaction between diol compounds and a tethered bilayer membrane (tBLM) in vitro using an SPR apparatus to elucidate the influence of diol compounds on a living cell membrane (Pavey et al., 1999; Green et al., 1997). The tBLM was fabricated by the vesicle fusion method using small unilamellar vesicles (SUVs) on a hydrophilic surface (Taylor et al., 2007; Chung et al., 2009).

\section{Synthesis of polyA-PEG-DPPE and polyT-BSA}

$\alpha-N$-Hydroxysuccinimidyl- $\omega$-maleimidyl poly(ethylene glycol) (NHSPEG-Mal, Mw: 5000) and 1,2-distearyl-sn-glycerol-3-phosphatidylethanolamine (DSPE) were purchased from the NOF Corporation (Tokyo, Japan). Mal-PEG-DPPE was synthesized by first dissolving NHS-PEG-Mal (180 $\mathrm{mg}$ ), triethylamine (50 $\mu \mathrm{L}$, Nacalai Tesuque, Kyoto, Japan), and DPPE 
(20 mg) in dichloromethane (Nacalai Tesuque) and stirring for $36 \mathrm{~h}$ at RT (Teramura et al., 2010a; Teramura et al., 2010b; Teramura et al., 2007). A white powder (190 mg, yield $80 \%$ ) was obtained by precipitation of the reaction mixture with diethyl ether. ${ }^{1} \mathrm{H}-\mathrm{NMR}\left(\mathrm{CDCl}_{3}, 400 \mathrm{MHz}, \delta \mathrm{ppm}\right)$ : $0.88\left(\mathrm{t}, 6 \mathrm{H},-\mathrm{CH}_{3}\right), 1.25$ (br, 56H, $\left.-\mathrm{CH}_{2}-\right) 3.64$ (br, 480H, PEG), 6.71 (s, $2 \mathrm{H},-\mathrm{HC}=\mathrm{CH}-$, maleimide).

Poly(adenosine phosphate) (20) (polyA) and poly(thymidine phosphate) (20) (polyT) carrying protected SH group at the 5'-ends were purchased from Sigma-Aldrich Chemical Co. (St. Louis, MO, USA). PolyA with a 5'-end $\mathrm{SH}$ group was prepared by reduction of the disulfide bond with DTT according to the manufacturer's instructions. The SH groups were conjugated to the Mal-PEG-lipid to prepare polyA-PEG-lipid. PolyA-SH $(1.0 \mathrm{mg})$ was mixed with Mal-PEG-DPPE $(5.0 \mathrm{mg})$ in PBS and incubated for $24 \mathrm{~h}$ at RT to prepare polyA-PEG-lipid (500 $\mu \mathrm{g} / \mathrm{mL}$ in PBS). PolyT-PEG-DPPE was prepared the same way as polyA-PEG-DPPE.

Bovine serum albumin (BSA) (Cohn V fraction, Sigma) in PBS (500 $\mu \mathrm{L}$ of a $20 \mathrm{mg} / \mathrm{mL}$ solution) was mixed with $20 \mu \mathrm{L}$ of $62.2 \mathrm{mg} / \mathrm{mL}$ sulfoEMCS ( $N$-(6-maleimidocaproyloxy) sulfo-succinimide, sodium salt; Thermo Scientific, USA) and incubated for $2 \mathrm{~h}$ at RT to introduce maleimide groups onto the BSA. Maleimide-conjugated BSA (BSA-Mal) was purified with a Sephadex ${ }^{\mathrm{TM}}$ G-25 M column (GE Healthcare UK Ltd., Buckinghamshire, UK). BSA-Mal solution ( $8.2 \mu \mathrm{L}$ of a $10 \mathrm{mg} / \mathrm{mL}$ solution) was mixed with $90 \mu \mathrm{L}$ of a $1.78 \mathrm{mg} / \mathrm{mL}$ polyT-SH solution, and the reaction mixture was incubated for $2 \mathrm{~h}$ at RT. This reaction mixture was used as a polyT-BSA solution.

\section{Small unilamellar vesicles (SUVs)}

L- $\alpha$-phosphatidylcholine (EggPC, Sigma) was dissolved in chloroform and put in a flask. The chloroform was removed to prepare a dry thin lipid film using a rotary evaporator. PBS was added to the lipid film and stirred vigorously at $4^{\circ} \mathrm{C}$ for 4 days to prepare lipid vesicles (lipid concentration $=$ $10 \mathrm{mg} / \mathrm{mL}$ ). The suspension was then extruded through membrane filters with pore size $0.8 \mu \mathrm{m}, 0.22 \mu \mathrm{m}$ (2 times), and $0.1 \mu \mathrm{m}$ (10 times) to form SUVs ( 100 nm diameter). PolyA-EggPC was prepared by incubation of SUVs with polyA-PEG-DPPE for $1 \mathrm{~h}$ at $37^{\circ} \mathrm{C}$.

\section{SPR measurements}

Glass plates (BK7, refractive index: 1.515, size: $25 \times 25 \times 1 \mathrm{~mm}$, Arteglass Associates Co., Kyoto, Japan) were immersed for $5 \mathrm{~min}$ in a piranha solution (a 7:3 mixture of concentrated sulfuric acid and $30 \%$ hydrogen peroxide), washed three times with deionized water, rinsed three times with Milli- $Q$ water and three times with 2-propanol, and finally stored in 2-propanol until use. The glass plates were dried under a stream of nitrogen gas and then mounted on the rotating stage of a thermal evaporation coating apparatus (V-KS200, Osaka Vacuum, Ltd., Osaka, Japan). A 1-nm chromium layer was deposited, and then a 49-nm gold layer was deposited.

This study used an SPR apparatus that was constructed in our laboratory (Hirata et al., 2000). A flow chamber with a gold-covered glass plate was placed on the prism of the SPR apparatus, and PBS was circulated at a flow rate of $4.0 \mathrm{~mL} / \mathrm{min}$ in the flow chamber for at least $5 \mathrm{~min}$. The reflectivity of a $p$-polarized $\mathrm{HeNe}$ laser beam $(\lambda=632.8 \mathrm{~nm})$ from the sample unit was monitored as a function of the incident angle. The least-squares method of the quadratic function was applied to points around the point of maximum loss of reflectivity, and the minimum point described by this fitted curve was defined as the resonance angle. The incident angle was then fixed at $0.5^{\circ}$ less than the resonance angle. For construction of a tethered bilayer membrane (tBLM), a $30 \mu \mathrm{g} / \mathrm{mL}$ polyT-BSA solution in PBS was introduced into the flow chamber, allowed to adsorb onto the Au surface for $20 \mathrm{~min}$, and then a $100 \mu \mathrm{g} / \mathrm{mL}$ polyA-EggPC solution in PBS was circulated for 1 h. To determine whether the diol solutions damaged the membrane, the EggPC tBLM was exposed to diol solutions [5, 10, 20, and 40\% (v/v) EG or PeD in PBS] for $5 \mathrm{~min}$, then washed with PBS for $5 \mathrm{~min}$. To express the degree of damage to the EggPC tBLM, the residual ratio of the EggPC tBLM was calculated as follows:

Residual ratio $=$ (SPR angle shift after exposure to the diol solution) / (SPR angle shift of the EggPC tBLM from the sensor surface).

\section{DSC measurements}

A differential scanning calorimeter (DSC, Diamond DCS, PerkinElmer, Inc. MA, USA) was used for thermal analysis of the cryopreservation solutions during the cooling process. The sample solutions were cooled from $0^{\circ} \mathrm{C}$ to $-140^{\circ} \mathrm{C}$ at a rate of $-150^{\circ} \mathrm{C} / \mathrm{min}$.

\section{hiPS cell culture}

hiPS cell line 253G4, established by transfection with OCT3/4, SOX2, and KLF4 (Nakagawa et al., 2008), and cell line 201B2, established by transfection with OCT3/4, SOX2, KLF4, and MYC, were the kind gift of Prof. Shinya Yamanaka. The hiPS cell line 253G1, established by transfection with OCT3/4, SOX2, and KLF4, was obtained from the RIKEN cell bank, Japan. Undifferentiated hiPS cells were maintained on a feeder layer of SNL76/7 cells (Thomas et al., 1987) treated with mitomycin C (Wako Pure Chemical, Osaka, Japan). SNL76/7 cells are a mouse fibroblast STO cell line that expresses the neomycin-resistance gene cassette and LIF (ECACC, UK). The undifferentiated hiPS cells and SNL76/7 feeder cells were cultured in Dulbecco's modified Eagle medium/F12 (DMEM/F12, Sigma) supplemented with $20 \%$ (v/v) knockout serum replacement (KSR; Invitrogen, Carlsbad, CA), $0.1 \mathrm{mM}$ nonessential amino acid (NEAA, Invitrogen), 2 mM L-glutamine (Sigma), 0.1 mM 2-mercaptoethanol (Sigma), $5 \mathrm{mM}$ sodium hydroxide, and $5 \mathrm{ng} / \mathrm{mL}$ FGF2 (Kaken Pharmaceutical Co., Ltd., Tokyo, Japan) in a humidified atmosphere of $5 \% \mathrm{CO}_{2}$ and $95 \%$ air at $37^{\circ} \mathrm{C}$. The hiPS cells were subcultured every $4-5$ days using $0.25 \%(\mathrm{v} / \mathrm{v})$ trypsin and $0.1 \mathrm{mg} / \mathrm{mL}$ collagenase (Type S-1, Nitta Gelatin Inc., Osaka, Japan) in PBS (-) supplemented with $20 \%$ (v/v) KSR and $1 \mathrm{mM}$ calcium chloride. The hiPS cells were suspended in PBS as cell clumps, but not single cells. SNL76/7 cells were routinely maintained in DMEM (Sigma) supplemented with $10 \%$ (v/v) fetal bovine serum (FBS, Equitech-Bio, Inc. TX, USA).

\section{Vitrification of hiPS cells}

\section{Liquid nitrogen preservation}

We examined the cryopreservation of hiPS cells using VS2E vitrification solution as well as the DAP213 vitrification solution developed by Fujioka et al., 2004. The compositions of the solutions are listed in Table 1. The VS2E and DAP213 solutions were sterilized by filtration through a membrane $(\phi: 0.22 \mu \mathrm{m})$ before use. Confluent hiPS cells in $60 \mathrm{~mm}$ dishes were harvested by treatment with trypsin and collagenase as described above. A pellet of hiPS cells was collected by centrifugation at $1000 \mathrm{rpm}$ for $5 \mathrm{~min}$ and resuspended in $200 \mu \mathrm{L}$ of a vitrification solution in a cryotube (1.8 mL, CryoTube ${ }^{\mathrm{TM}}$ Vials, Nunc ${ }^{\mathrm{TM}}$, Denmark). The cryotube was immediately immersed in liquid nitrogen and stored for 7 days until recovery rate determination was conducted.

\section{Recovery rate of hiPS cells after liquid nitrogen preservation}

Culture medium $(1 \mathrm{~mL})$ pre-warmed to $37^{\circ} \mathrm{C}$ was added directly to vitrified hiPS cells $(200 \mu \mathrm{L})$ in the cryotube, followed by rapid pipetting. The hiPS cell suspension was immediately transferred to a centrifuge tube and spun at $1000 \mathrm{rpm}$ for $3 \mathrm{~min}$ at RT. The supernatant was removed, the cell pellet was resuspended in $4 \mathrm{~mL}$ of culture medium, and the cell suspension was applied to a feeder-layer of SNL76/7 in a culture dish and cultured at $37^{\circ} \mathrm{C}, 5 \% \mathrm{CO}_{2}$. In the procedure, we carefully treated cells not to disperse into single cells, but to maintain cell clumps, because hiPS cells hardly proliferate when they were seeded as a single cell.

Cell colonies were observed under a phase contrast microscope after 1 day of culture. For a control experiment, hiPS cells without cryopreservation were seeded onto a SNL feeder-layer. To determine the recovery rates of hiPS cells after cryopreservation, cell colonies formed on the SNL cell layer were counted 1 day after culture. Recovery rates were calculated as follows:

Recovery rate $(\%)=100 \times$ (the number of cell colonies formed by hiPS cells after preservation under liquid nitrogen) / (the number of cell colonies formed by hiPS cells without preservation). 


\section{Pluripotency of hiPS cells after liquid nitrogen preservation}

In vitro histochemical analysis of hiPS cells after preservation in liquid nitrogen

After thawing and 4 days of culture, cells were fixed in $4 \%(\mathrm{w} / \mathrm{v})$ paraformaldehyde (PFA) in PBS for 15 min and permeabilized by treatment with $0.2 \%(\mathrm{v} / \mathrm{v})$ Triton X-100 solution for $15 \mathrm{~min}$ at RT. After treatment with the Blocking One ${ }^{\circledR}$ reagent (Nacalai Tesque) at $\mathrm{RT}$ for $1 \mathrm{~h}$, cells were incubated with primary antibodies for $12 \mathrm{~h}$ at $4^{\circ} \mathrm{C}$. The dilution ratios of the primary antibodies were as follows: mouse anti-SSEA-4, 1:400 (Chemicon, CA), and rabbit anti-Oct3/4, 1:200 (Santa Cruz Biotechnology, CA) (diluted in Blocking One ${ }^{\circledR}$ solution). The sample cells were washed in $0.05 \%(\mathrm{w} / \mathrm{v})$ polyoxyethylene sorbitan monolaurate (Tween 20, in PBS, Wako) three times and then incubated with secondary antibodies for $2 \mathrm{~h}$ at RT. The dilution ratios of the secondary antibodies were as follows: Alexa Fluor ${ }^{\circledR}$ 488-labeled goat anti-mouse IgG, 1:500 (Invitrogen), and Alexa Fluor® 594-labeled goat anti-rabbit IgG, 1:500 (Invitrogen) (diluted in Blocking One® solution). To stain cell nuclei, the sample cells were incubated with Hoechst 33342 fluorescent dye (Dojindo Laboratories, Kumamoto, Japan) at a dilution of 1:500 in PBS for 15 min at RT. After washing with PBS, the sample cells were observed under a fluorescent microscope (IX71, Olympus Optical Co. Ltd., Tokyo, Japan). The alkaline phosphatase activity of the hiPS cells was visualized after fixation with PFA using the Alkaline Phosphatase Substrate Kit III (Vector Laboratories, Burlingame, CA, USA).

Teratoma formation by hiPS cells after preservation in liquid nitrogen using VS2E

hiPS cells were preserved under liquid nitrogen using VS2E and cultured for 1 passage. Cells were treated with $10 \mu \mathrm{M}$ Y-27632 (Wako) for $1 \mathrm{~h}$ at $37^{\circ} \mathrm{C}$ before collection from the $100-\mathrm{mm}$ culture dishes. Cells from a single dish were subcutaneously injected into the backs (right and left sides) of SCID mice. After 12 weeks, teratomas were removed and fixed in $4 \%$ (w/v) PFA solution overnight. Paraffin-embedded tissue sections (4 $\mu \mathrm{m}$ ) were prepared using standard methods and stained with hematoxylin and eosin (HE) for visual examination.

\section{Statistical analysis}

Comparisons between two groups were made using Student's $t$-tests, and $p<0.05$ was considered statistically significant. All statistical calculations were performed using statistical software (JMP 6.0).

\section{Acknowledgements}

This study was supported in part by a Grant-in-Aid for Scientific Research (A) (No. 21240051), by a Challenging Exploratory Research Grant (No. 21650118) from the Ministry of Education, Culture, Sports, Science, and Technology (MEXT) of Japan, and by the Ministry of Health, Labor, and Welfare of Japan (H20-007).

\section{References}

AGUDELO, C.A., and IWATA, H. (2008). The development of alternative vitrification solutions for microencapsulated islets. Biomaterials 29: 1167-1176.

AGUDELO, C.A., TERAMURA, Y., and IWATA, H. (2009). Cryopreserved agaroseencapsulated islets as bioartificial pancreas: a feasibility study. Transplantation 87: 29-34.

AMEEN, C., STREHL, R., BJORQUIST, P., LINDAHL, A., HYLLNER, J., and SARTIPY, P. (2008). Human embryonic stem cells: Current technologies and emerging industrial applications. Crit. Rev. Oncol. Hematol. 65: 54-80.

CHUNG, M., LOWE, R.D., CHAN, Y.H.M., GANESAN P.V., and BOXER, S.G. (2009). DNA-tethered membranes formed by giant vesicle rupture. J. Struct. Biol. 168: 190-199

GLAASSEN, D.A., DESLER, M.M., and RIZZINO, A. (2009). ROCK inhibition enhances the recovery and growth of cryopreserved human embryonic stem cells and human induced pluripotent stem cells. Mol. Reprod. Dev. 76: 722-732.

FUJIOKA, T., YASUCHIKA, K., NAKAMURA, Y., NAKATSUJI, N., and SUEMORI,
H. (2004). A simple and efficient cryopreservation method for primate embryonic stem cells. Int. J. Dev. Biol. 48: 1149-1154.

GREEN, R.J.,DAVIES, J., DAVIES, M.C., ROBERTS, C.J., and TENDLERS.J. (1997) Surface plasmon resonance for real time in situ analysis of protein adsorption to polymer surfaces. Biomaterials 18: 405-413.

HIRATA, I., MORIMOTO, Y., MURAKAMI, Y., IWATA, H., KITANO, E., and KITAMURA H. (2000). Study of complement activation on well-defined surfaces using surface plasmon resonance. Colloids Surf. B 18: 285-292.

JI, L., de PABLO, J., and PALECEK, S.P. (2004). Cryopreservation of adherent human embryonic stem cells. Biotechnol. Bioeng. 88: 299-312.

KATKOV I.I., KIM M.S., BAJPAI, R., ALTMAN, Y.S., MERCOLA, M., LORING, J.F., TERSKIKH, A.V., SNYDER, E.Y., and LEVINE, F. (2006). Cryopreservation by slow cooling with DMSO diminished production of Oct-4 pluripotency marker in human embryonic stem cells. Cryobiology 53: 194-205

KELLER, G., and SNODGRASS, H.R. (1999). Human embryonic stem cells: the future is now. Nat. Med. 5: 151-152.

LI, X., KRAWETZ, R., LIU, S., MENG, G., and RANCOURT, D.E. (2009). ROCK inhibitor improves survival of cryopreserved serum/feeder-free single human embryonic stem cells. Hum. Reprod. 24: 580-589.

MARTIN-IBAÑEZ, R., UNGER, C., STRÖMBERG, A., BAKER, D., CANALS, J.M., and HOVATTA, O. (2008). Novel cryopreservation method for dissociated human embryonic stem cells in the presence of a ROCK inhibitor. Hum. Reprod. 23 2744-2754.

MOLLAMOHAMMADI, S., TAEI, A., PAKZAK, M., TOTONCHI, M., SEIFINEJAD, A., MASOUDI, N., and BAHARVAND, H. (2009). Simple and efficient cryopreservation method for feeder-free dissociated human induced pluripotent stem cells and human embryonic stem cells. Hum. Reprod. 24: 2468-2476.

NAKAGAWA, M., KOYANAGI, M., TANABE, K., TAKAHASHI, K., ICHISAKA, T. AOI, T., OKITA, K., MOCHIDUKI, Y., TAKIZAWA, N., and YAMANAKA, S. (2008). Generation of inducek pluripotent stem cells without Myc from mouse and human fibroblasts. Nat. Biotechnol. 26: 101-106.

NISHIGAKI, T., TERAMURA, Y., SUEMORI, H., and IWATA, H. (2010). Cryopreservation of primate embryonic stem cells with chemically-defined solution without $\mathrm{Me}_{2} \mathrm{SO}$. Cryobiology 60: 159-164.

PAVEY, K.D. and OLLIFF, C.J. (1999). SPR analysis of the total reduction of protein adsorption to surfaces coated with mixtures of long- and short-chain polyethylene oxide block copolymers. Biomaterials 20: 885-890.

REUBINOFF, B.E., PERA, M.F., VAJTA, G., and TROUSON, A.O. (2001). Effective cryopreservation of human embryonic stem cells by open pulled straw vitrification method. Hum. Reprod. 16: 2187-2194.

RICHARDS, M., FONG, C.Y., TAN, S., CHAN, W.K., and BONGSO, A. An efficient and safe xeno-free cryopreservation method for the storage of human embryonic stem cells. (2004). Stem Cells 22: 779-789.

SPERGER, J.M., CHEN, X., DRAPER, J.S., ANTOSIEWICZ, J.E., CHON, C.H. JONES, S.B., BROOKS, J.D., ANDREWS, P.W., BROWN, P.O., and THOMSON, J.A. (2003). Gene expression patterns in human embryonic stem cells and human pluripotent germ cell tumors. Proc. Natl. Acad. Sci. USA. 100: 13350-13355.

TAKAHASHI, K., TANABE, K., OHNUKI, M., NARITA, M., ICHISAKA, T., TOMODA, K., and YAMANAKA, S. (2007). Induction of pluripotent stem cells from adult human fibroblasts by defined factors. Cell 131: 861-872.

TAKAMUKU, T., TSUTSUMI, Y., MATSUGAMI, T., and YAMAGUCHI, T. (2008). Thermal Properties and Mixing State of Diol-Water Mixtures Studied by Calorimetry, LargeAngleX-Ray Scattering, and NMR Relaxation. J. Phys. Chem. B112: 13300-13309

TAYLOR, J.D., PHILLIPS, K.P., and CHENG, Q. (2007). Microfluidic fabrication of addressable tethered lipid bilayer arrays and optimization using SPR with silanederivatized nanoglassy substrates. Lab Chip 7: 927-930

TERAMURA, Y., CHEN, H., KAWAMOTO, T., and IWATA, H. (2010b). Control of cell attachment through polyDNA hybridization. Biomaterials 31: 2229-2235

TERAMURA, Y., KANEDA, Y., and IWATA, H. (2007). Islets-Encapsulation with Ultra-thin Layer-by-Layer Membranes of Poly(vinyl alcohol) through Poly(ethylene glycol)-lipids Anchored to Cell Surface. Biomaterials, 28, 4818-4825

TERAMURA, Y., LUAN, M.N., KAWAMOTO, T., and IWATA, H. (2010a). Microencapsulation of Islets with Living Cells Using PolyDNA-PEG-Lipid Conjugate. Bioconjugate Chem, 21: 792-796.

THOMAS, K.R., and CAPECCHI, M.R. (1987). Site-directed mutagenesis by gene targeting in mouse embryo-derived stem cells. Cell 51: 503-512. 
THOMSON, J.A., KALISHMAN, L., GOLOS, T.G., DURNING, M., HARRIS, C.P., THOMSON, J.A., ITSKOVITZ-ELDOR, J., SHAPIRO, S.S., WAKNITZ, M.A., SWIERGIEL, J.J., MARSHALL, V.S. and JONES, J. (1998). Embryonic stem cell lines derived from human blastocysts. Science 282: 1145-1147.
YU, J., VODYANIK, M.A., SMUGA-OTTO, K., ANTOSIEWICZ-BOURGET, J., FRANE, J.L., TIAN, S., NIE, J., JONSDOTTIR, G.A., RUOTTI, V., STEWART, R., SLUKVIN, I.I., and THOMSON, J.A. (2007). Induced pluripotent stem cell lines derived from human somatic cells. Science 318: 1917-1920. 


\section{Further Related Reading, published previously in the Int. J. Dev. Biol.}

Challenges and strategies for generating therapeutic patient-specific hemangioblasts and hematopoietic stem cells from human pluripotent stem cells

Ann Peters, Paul W. Burridge, Marina V. Pryzhkova, Michal A. Levine,Tea-Soon Park, Christopher Roxbury, Xuan Yuan, Bruno Péault and Elias T. Zambidis

Int. J. Dev. Biol. (2010) 54: 965-990

Feeder- and serum-free establishment and expansion of human induced pluripotent stem cells

Mehdi Totonchi, Adeleh Taei, Ali Seifinejad, Mohammadsharif Tabebordbar, Hassan Rassouli, Ali Farrokhi, Hamid Gourabi, Nasser Aghdami, Ghasem Hosseini-Salekdeh and Hossein Baharvand

Int. J. Dev. Biol. (2010) 54: 877-886

Mouse induced pluripotent stem cells

Eamon Geoghegan and Lucy Byrnes

Int. J. Dev. Biol. (2008) 52: 1015-1022

Pluripotency and differentiation in embryos and stem cells - Pavia, 17-18 January 2008

James A. Adjaye, Anne G. Byskov, Jose B. Cibelli, Ruggero De Maria, Stephen Minger, Maurilio Sampaolesi, Giuseppe Testa, Catherine Verfaillie, Magdalena Zernicka-Goetz, Hans Schöler, Michele Boiani, Nicola Crosetto and Carlo A. Redi

Int. J. Dev. Biol. (2008) 52: 801-809

A simple and efficient cryopreservation method for primate embryonic stem cells

Tsuyoshi Fujioka, Kentaro Yasuchika, Yukio Nakamura, Norio Nakatsuji and Hirofumi Suemori

Int. J. Dev. Biol. (2004) 48: 1149-1154

5 yr ISI Impact Factor $(2009)=3.253$

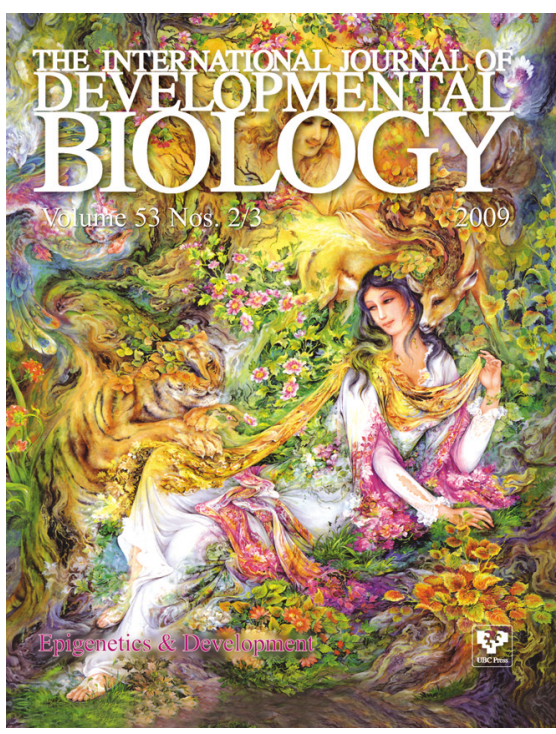

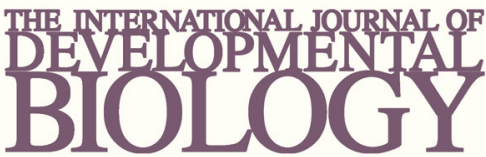

Volume 54 Nos. $6 / 7$

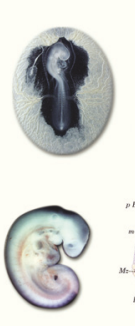

Developmental Hematopoiesis
Special Issue

\$2

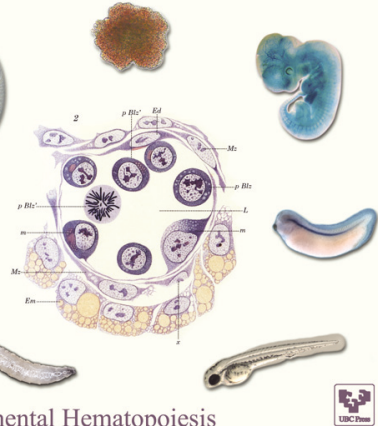

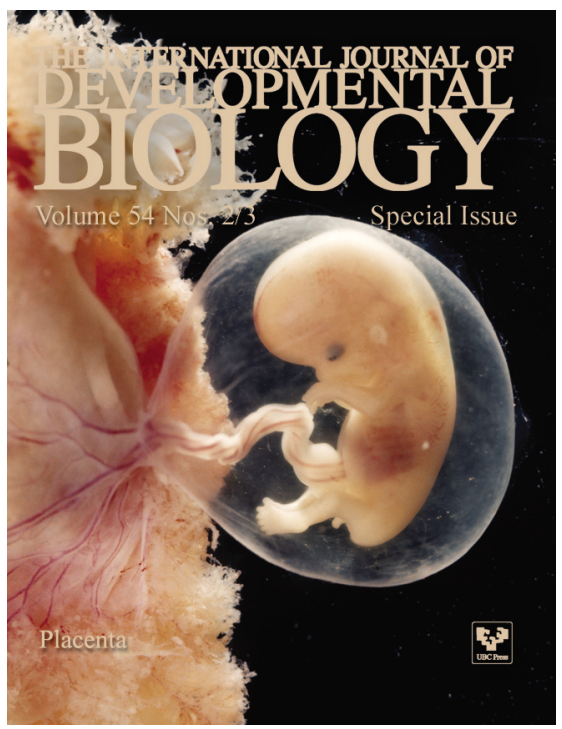

